\title{
NOTES
}

\section{Revival of the Name Clostridium aceticum}

\author{
GERHARD GOTTSCHALK AND MANFRED BRAUN \\ Institut für Mikrobiologie der Universität Göttingen, D-3400 Göttingen, West Germany
}

\begin{abstract}
The name Clostridium aceticum Wieringa 1940 was omitted from the Approved Lists of Bacterial Names. The name is here revived and validly published as Clostridium aceticum sp. nov., nom. rev. in accordance with Rules 27 and 28a and Provisional Rules $\mathrm{B}_{2}$ and $\mathrm{B}_{3}$ of the International Code of Nomenclature of Bacteria. The type strain is DSM 1496.
\end{abstract}

The name Clostridium aceticum Wieringa 1940 was not included on the Approved Lists of Bacterial Names (5) because it was thought that the original isolate was lost. This microorganism was first isolated in 1936 (6), and certain aspects of its physiology were subsequently studied (3, 7 ). After 1948, cultures of C. aceticum were not available, and attempts to reisolate it were unsuccessful. A viable spore preparation of the original strain of $C$. aceticum has been discovered recently, and a complete description of this species has been published (2).

C. aceticum Wieringa 1940 is rod shaped; it is 0.8 to $1.0 \mu \mathrm{m}$ wide and about $5 \mu \mathrm{m}$ long when it is grown chemolithotrophically and up to $40 \mu \mathrm{m}$ long when it is grown with fructose as the substrate. The cells are motile and peritrichous. Round spores are formed in the polar cell region. The Gram reaction is negative. The deoxyribonucleic acid of $C$. aceticum contains $33 \mathrm{~mol} \%$ guanine plus cytosine.

Chemolithotrophic growth with molecular hydrogen and carbon dioxide occurs at $30^{\circ} \mathrm{C}$ and pH $8.3 ; 4 \mathrm{~mol}$ of molecular hydrogen and $2 \mathrm{~mol}$ of carbon dioxide are converted to $1 \mathrm{~mol}$ of acetic acid. $C$. aceticum is also able to grow chemoorganotrophically. The following substrates are utilized as carbon and energy sources: D-fructose, D-ribose, L-glutamate, L-malate, L-serine, pyruvate, formate, and ethanol. The principal metabolic product is acetate. Depending on the redox grade of the substrate, carbon dioxide is either produced or is required, in the latter case being reduced to acetate.

In contrast to all other clostridial species, $C$. aceticum is able to grow at the expense of acetate formation from $\mathrm{H}_{2}$ and $\mathrm{CO}_{2}$. This property is the main difference between $C$. aceticum and Clostridium formicoaceticum (1). Only minor differences have been observed with respect to the ability of these two species to utilize organic substrates. Methanol serves as a substrate for $C$. formicoaceticum but not for $C$. aceticum. The opposite has been observed for formate. A detailed comparison of these two species has been presented previously in connection with the description of $C$. aceticum (2).

The name Clostridium aceticum sp. nov. is here revived for the same organism to which the name was originally applied, in accordance with Rules 27 and 28a and Provisional Rules $B_{2}$ and $\mathrm{B}_{3}$ of the International Code of Nomenclature of Bacteria (4). The type strain of $C$. aceticum (2) is DSM 1496. The description of the type strain is identical to that of the species (2).

\section{REPRINT REQUESTS}

Address reprint requests to: Gerhard Gottschalk, Institut für Mikrobiologie der Universität Göttingen, Grisebachstrasse 8, D-3400 Göttingen, West Germany.

\section{LITERATURE CITED}

1. Andreesen, J. R., G. Gottschalk, and H. G. Schlegel. 1970. Clostridium formicoaceticum nov. spec. Isolation, description and distinction from $C$. aceticum and $C$. thermoaceticum. Arch. Mikrobiol. 72:154-174.

2. Braun, M., F. Mayer, and G. Gottschalk. 1981. Clostridium aceticum (Wieringa), a microorganism producing acetic acid from molecular hydrogen and carbon dioxide. Arch. Microbiol. 128:288-293.

3. Karlsson, J. L., B. E. Volcani, and H. A. Barker. 1948. The nutritional requirements of Clostridium aceticum. J. Bacteriol. 56:781-782.

4. Lapage, S. P., P. H. A. Sneath, E. F. Lessel, V. B. D. Skerman, H. P. R. Seeliger, and W. A. Clark (ed.). 1975. International code of nomenclature of bacteria. 1975 Revision. American Society for Microbiology, Washington, D.C.

5. Skerman, V. B. D., V. McGowan, and P. H. A. Sneath (ed.). 1980. Approved lists of bacterial names. Int. J. Syst. Bacteriol. 30:225-420.

6. Wieringa, K. T. 1936. Over het verdwijnen van waterstof en koolzuur onder anaerobe voorwaarden. Antonie van Leeuwenhoek J. Microbiol. Serol. 3:263-273.

7. Wieringa, K. T. 1940 . The formation of acetic acid from carbon dioxide and hydrogen by anaerobic spore-forming bacteria. Antonie van Leeuwenhoek J. Microbiol. Serol. 6:251-262. 